\title{
The Thai Financial Crisis And The Sufficiency Economy Philosophy
}

\author{
Vilasinee Bunyasrie, Bangkok University International College, Thailand
}

\begin{abstract}
This article revisits the financial crisis in 1997 using the sufficiency economy philosophy bestowed by His Majesty the King Bhumibol Adulyadej, shading some light on what went wrong, the lessons learnt, and possibly what can be done to prevent such crisis from happening again. The origin of the crisis was the fact that Thai economy grew too fast with the help of the financial liberalization in early 1990s. This rapid growth, however, violated the three elements of the sufficiency economy, which are moderation, reasonableness and self-immunity, in turns, exposed the country to trouble. On July 2, 1997, Thai land had to let the baht float freely, and that when the crisis started. More than ten years have passed, and we believe that we will not make the same mistakes again if we follow the sufficiency economy philosophy. The application of the philosophy is not limited only to the national level, but it is applicable to people from all walks of life at all levels. The philosophy can be boiled down to five axioms; (1) know what you are doing; (2) be honest and persevere; (3) take middle path; (4) be sensible and insightful in taking decisions; (5) build protection against shocks despite different applications, they all share the same goal of balanced and sustainable development.
\end{abstract}

Keywords: Financial Crisis, Sufficiency Economy and Thai Economy

\section{INTRODUCTION}

$\mathscr{\mathcal { C }}$ region and beyond.

Now, ten years have passed since the financial crisis. In many ways, an air of normality as returned. But, despite, the recovery, it is perhaps time to look back at the causes of the crisis, the lessons learnt and what can be done to prevent the crisis from happening again. As a result of the financial crisis, His Majesty the King Bhumibol Adulyadej advised Thai people to change their economic philosophy in order to cope with present economic adversity and withstand economic insecurity. His Majesty's words have become known as the philosophy of "Sufficiency Economy". The sufficiency economy is a philosophy bestowed by His Majesty the King to his subjects through royal remarks on many occasions over the past three decades. The philosophy provides guidance on appropriate conduct covering numerous aspects of life that will lead to a sustainable way of living, be able to meet the challenges arising from globalization and other changes. After the economic crisis in 1997, His Majesty reiterated and expanded on the Sufficiency Economy in remarks made in December 1997 and 1998. The philosophy points the way for recovery that will lead to more resilient and sustainable economy, better able to meet the challenges arising from globalization and other changes ${ }^{1}$. According to his Majesty the King, Sufficiency Economy is a philosophy that stresses the middle path as an overriding principle for appropriate conduct by the people at all levels. This applies conduct starting from the level of the families, communities, as well as the level of nation in development and administration so as to modernize in line with forces of globalization. "Sufficiency" means moderation, reasonableness, and the need for self-immunity for sufficient protection from impact arising from internal and external changes. To achieve this, an application of knowledge with due consideration and prudence is

1 The 1999 TDRI Year-End Conference Distribution Material 
essential. At the same time, it is important to strengthen the moral fiber of the nation, so that everyone, particularly public officials, academic, businessmen at all levels, adheres first and foremost to the principles of honesty and integrity. In addition, a way of life based on patience, perseverance, diligence, wisdom and prudence to create balance and be able to cope appropriately with critical challenges arising from extensive and rapid socioeconomic, environmental, and cultural changes in the world ${ }^{2}$. The philosophy of the sufficiency economy includes three elements: moderation, reasonableness and self-immunity, and requires two conditions for the philosophy to work: knowledge and ethics, as illustrated in the following diagram;

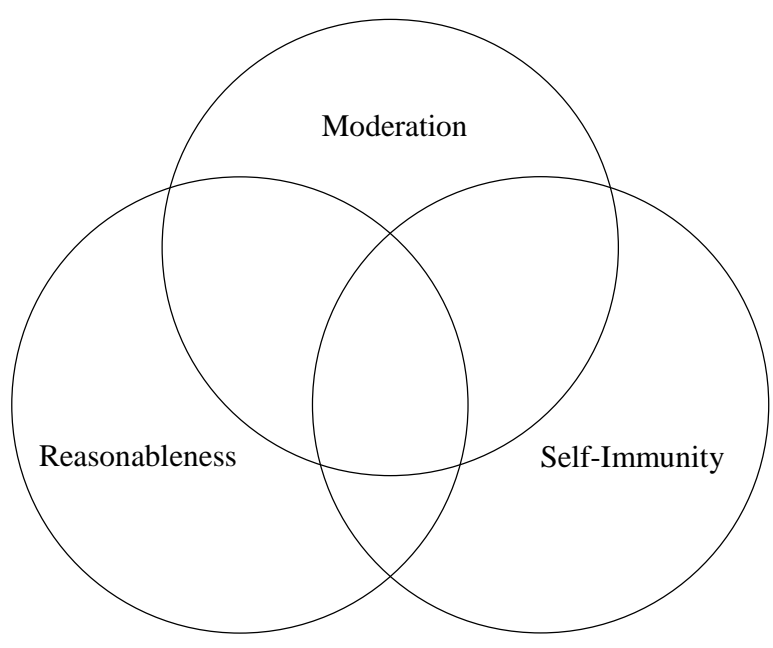

\section{NOT-SO-SUFFICIENT BEHAVIORS PRIOR TO THE CRISIS}

We will take a look back on the Thai economy during the pre-crisis period, using the sufficiency economy philosophy, in order to analyze what went wrong that led to the financial crisis in 1997. In the decade leading up to the crisis, economic growth in Thailand averaged 8.6 percent a year. In the middle and late 1980s, a remarkable combination of international phenomena came together to "make a miracle" in Thailand: an acceleration of real economic growth from about 6 percent per year in 1976-1985 to above 8 percent in 1986-1995. At its peak in 19881990, growth averaged 12 percent per year. Low wages, progressive reductions in trade barriers, and years of conservative macroeconomic management resulting in low inflation and a stable exchange rate made the Thai economy an ideal host for a flood of foreign investment in the late 1980s, especially that from Japan after the Plaza Accord and the subsequent appreciation of the yen relative to the US dollar. The same factors enabled Thai exporters to ride a tremendous wave of growth in global trade from the mid-1980s. However, an assessment of Thailand's past development reveals imbalance and inflexibility in many ways that is developmental achievements appear in the form of quantity rather than quality. While Thailand has made great progress in reducing poverty, the income gap is still very large. Basic infrastructure has expanded nationwide, but the distribution is not balanced and more importantly, the quality is uneven. Thailand's development has resulted in better health and education of a large number of people; however, the quality does not match the quantity. Services do not cover all targeted areas. At the same time, ethics, morals and disciplines have weakened. The administration and institutions such as political sector, public sector, private businesses, communities and family, do not have the necessary tools to protect them from internal and external volatility.

Our experiences in the past confirmed that Thailand exposed itself to the globalization excessively; therefore, put the country into trouble by violating the three elements of the sufficiency economy's philosophy, as following;

\footnotetext{
${ }^{2}$ Summarized from H.M. the King's remarks related to sufficiency economy on various occasions.
} 
Moderation: The households' saving rate in Thailand declined from approximately 14 percent in 1988 to approximately 5 percent in 1996, which shows the pattern of over-consumption. Moreover, private businesses resorted to debt rather than equity to finance investment, especially short-term foreign debt which was the result from the financial liberalization in the early 1990s. The financial liberalization in Thailand started to create problems that led to the crisis in 1997. Of all the financial liberalization measures, the establishment of offshore banking facilities, known as the Bangkok International Banking Facilities (BIBFs), was the most important. BIBFs were introduced in 1993 in order to facilitate and reduce the cost of international borrowing while encouraging foreign capital inflows to finance domestic investment and investment throughout South East Asia. However, financial liberalization, aimed to promoting stiffer competition among financial institutions, brought in excessive capital inflows and foreign borrowing too quickly and beyond moderation as guided in sufficiency economy. The easier access to the funds together with the nature of the Thai financial system, where banks and other financial institutions were mostly family-owned, nepotism led to corrupted lending practices brought about the crisis. The violation the moderation element of the sufficiency economy resulted in excessive borrowing and lending by financial institutions as well as excessive investing, especially in land and real estate during the economic boom in the 1990s. The evidence on the lending boom in the 1990s is provided by the data on the growth of bank credit to private sector in Table 1, and the ratio of private sector lending to GDP in Table 2.

Table 1. Bank Lending to Private Sector (\% growth)

\begin{tabular}{|l|c|c|c|c|c|c|c|}
\hline & $\mathbf{1 9 9 1}$ & $\mathbf{1 9 9 2}$ & $\mathbf{1 9 9 3}$ & $\mathbf{1 9 9 4}$ & $\mathbf{1 9 9 5}$ & $\mathbf{1 9 9 6}$ & $\mathbf{1 9 9 7}$ \\
\hline Korea & 20.78 & 12.55 & 12.94 & 20.08 & 15.45 & 20.01 & 21.95 \\
\hline Indonesia & 17.82 & 12.29 & 25.48 & 22.97 & 22.57 & 21.45 & 46.42 \\
\hline Malaysia & 20.58 & 10.79 & 10.80 & 16.04 & 30.65 & 25.77 & 26.96 \\
\hline Philippines & 7.33 & 24.66 & 40.74 & 26.52 & 45.39 & 48.72 & 28.79 \\
\hline Singapore & 12.41 & 9.77 & 15.15 & 15.25 & 20.26 & 15.82 & 12.68 \\
\hline Thailand & 20.45 & 20.52 & 24.03 & 30.26 & 23.76 & 14.63 & 19.80 \\
\hline Hong Kong & & 10.17 & 20.15 & 19.94 & 10.99 & 15.75 & 20.10 \\
\hline China & 19.76 & 20.84 & 43.52 & 24.58 & 24.23 & 24.68 & 20.96 \\
\hline Taiwan & 21.25 & 28.70 & 19.46 & 16.18 & 10.00 & 6.00 & 8.92 \\
\hline
\end{tabular}

Source: NBER Working Paper No.6833

Table 2. Bank Lending to Private Sector (\% GDP)

\begin{tabular}{|l|c|c|c|c|c|c|c|c|}
\hline & $\mathbf{1 9 9 0}$ & $\mathbf{1 9 9 1}$ & $\mathbf{1 9 9 2}$ & $\mathbf{1 9 9 3}$ & $\mathbf{1 9 9 4}$ & $\mathbf{1 9 9 5}$ & $\mathbf{1 9 9 6}$ & $\mathbf{1 9 9 7}$ \\
\hline Korea & 52.54 & 52.81 & 53.34 & 54.21 & 56.84 & 57.04 & 61.81 & 69.79 \\
\hline Indonesia & 49.67 & 50.32 & 49.45 & 48.90 & 51.88 & 53.48 & 55.42 & 69.23 \\
\hline Malaysia & 71.36 & 75.29 & 74.72 & 74.06 & 74.61 & 84.80 & 93.39 & 106.91 \\
\hline Philippines & 19.17 & 17.76 & 20.44 & 26.37 & 29.06 & 37.52 & 48.98 & 56.53 \\
\hline Singapore & 82.20 & 83.34 & 85.06 & 84.14 & 84.21 & 90.75 & 95.96 & 100.29 \\
\hline Thailand & 64.30 & 67.70 & 72.24 & 80.01 & 91.00 & 97.62 & 101.94 & 116.33 \\
\hline Hong Kong & & 141.84 & 134.20 & 140.02 & 149.00 & 155.24 & 162.36 & 174.24 \\
\hline China & 85.51 & 87.87 & 86.17 & 95.49 & 87.12 & 85.83 & 91.65 & 101.07 \\
\hline Taiwan & 100.41 & 108.99 & 126.43 & 137.23 & 146.89 & 149.49 & 146.05 & 146.23 \\
\hline
\end{tabular}

Source: NBER Working Paper No.6833

Reasonableness: The financial liberalization allowed easier access to funds from abroad. Since most of the credits were on a short-term basis and continually rolled over for long-term use, it created a problem of maturity mismatching. Moreover, during the period leading up to the crisis, Thailand also faced quality problem of the loans where the funds used to finance investments of dubious profitability or speculative purchase of existing financial assets such as investments in real estate and property sectors, resulting in non-performing loans arise from these risky and poor performing projects as shown in Table 3. 
Table 3. Non-Performing Loans (as proportion of total lending in 1996)

\begin{tabular}{|l|c|}
\hline Korea & $8 \%$ \\
\hline Indonesia & $13 \%$ \\
\hline Malaysia & $10 \%$ \\
\hline Philippines & $14 \%$ \\
\hline Singapore & $4 \%$ \\
\hline Thailand & $13 \%$ \\
\hline Hong Kong & $3 \%$ \\
\hline China & $14 \%$ \\
\hline Taiwan & $4 \%$ \\
\hline
\end{tabular}

Source: 1997 BIS Annual Report

This event was against the reasonableness element of the sufficiency economy, and fueled a spree of speculative spending practices in many sectors of the Thai economy which finally led to the crisis. More importantly, the origin of problems of the Thai financial system was the concentration of bank ownership. Familyowned banks caused imprudent managements, such as unscrupulous lending practices, maturity mismatching and excessive exchange risks: the basket pegged exchange rate system encouraged large, unhedged foreign borrowing because the pegged exchange rate eliminated risks from borrowing in foreign currencies thus when the Bank of Thailand floated the baht on July 2, 1997, foreign debt values were raised and the crisis was exacerbated. Moreover, fierce competition in the region to become a financial center also led to policy implementation that aims to attract investment and capital inflows with less careful risk assessment.

Self-Immunity: At the macro level, macroeconomic policy did not provide appropriate immunization against external volatility. The country lacked mechanisms to balance risks from volatility from financial liberalization with the potential benefits liberalization offered. The fact that domestic banks borrowed heavily from foreign banks but lent mostly to domestic investors, and a very large fraction of foreign debt accumulation was in the form of shortterm, unhedged, foreign-currency dominate liabilities which exposed the Thai economy to the risks of easily reversing of short-term capital and foreign exchange rate fluctuations. In normal times high foreign liabilities may not cause a concern, as short-term foreign debts are easily rolled over. In the presence of rapid currency depreciation, however, this may cause serious financial problems especially if the foreign borrowing is in foreign currency, while the domestic lending is in domestic currency. Foreign lenders might suddenly refuse to roll over short-term lines for credit to domestic banks, precipitating the crisis as happened in 1997. Moreover, the debt denominated in foreign currencies ended up exacerbating the exchange rate crisis, as the depreciation of the baht increased the real burden of foreign debts. In other words, Thailand's financial status was tied to other countries' economic activities, therefore, made itself vulnerable to external shocks, sudden switches in market confidence and sentiment, which was driven by deteriorating expectation about the poor state of fundamentals. In 1997 the drop of the real estate and stock markets, where sustained speculative trends were mostly fueled by foreign capital inflows, led to the emergence of wide losses and outright defaults in the corporate and financial sectors, and rapid reversals of financial capital inflows led to collapse of the baht amidst domestic and international investors panic. Apart from being financially independent, Thailand also relied heavily on international trade (Table 4), which tied its economy even more closely to foreign countries', since greater trade openness also makes the country more vulnerable to terms of trade shocks and to restrictive trade policies in trade partner countries. These financially as well as trade dependency caused Thailand to lack self-immunity element of the sufficiency economy philosophy.

Table 4. Trade Openness ((Exports+Imports)/2 as a \% of GDP)

\begin{tabular}{|l|c|c|c|c|c|c|c|c|}
\hline & $\mathbf{1 9 9 0}$ & $\mathbf{1 9 9 1}$ & $\mathbf{1 9 9 2}$ & $\mathbf{1 9 9 3}$ & $\mathbf{1 9 9 4}$ & $\mathbf{1 9 9 5}$ & $\mathbf{1 9 9 6}$ & $\mathbf{1 9 9 7}$ \\
\hline Korea & 30.04 & 29.38 & 29.38 & 29.04 & 30.47 & 33.59 & 34.36 & 38.48 \\
\hline Indonesia & 26.30 & 27.18 & 28.23 & 25.26 & 25.94 & 26.98 & 26.13 & 28.22 \\
\hline Malaysia & 75.23 & 86.52 & 76.64 & 87.72 & 92.15 & 97.42 & 91.50 & 93.55 \\
\hline Philippines & 30.40 & 31.09 & 31.58 & 35.58 & 36.98 & 40.26 & 44.90 & 54.20 \\
\hline Thailand & 37.76 & 39.24 & 38.98 & 39.69 & 40.99 & 44.88 & 42.19 & 46.69 \\
\hline Hong Kong & 129.93 & 135.28 & 140.37 & 137.18 & 138.92 & 151.67 & 142.28 & 132.68 \\
\hline Taiwan & 44.27 & 45.14 & 42.34 & 43.29 & 43.16 & 47.80 & 46.63 & 48.07 \\
\hline
\end{tabular}

Source: NBER Working Paper No.6833 


\section{WHERE DO WE GO FROM HERE?}

Past development has led to a society that is too receptive of external influences without due screening. The liberalization policy was implemented without sufficient institutional preparation. The country also lacked appropriate warning systems, immunity and mechanism to adjust itself in time of crisis. While opening to trade and capital flows have benefited the country in its development and growth, negative effect of external volatility need careful assessment and management. Development of the financial and capital markets in the sufficiency economy perspective primarily lies in the need to foster the country's immunization against external volatility. The country should promote higher level of domestic saving, lower level of dependence on external capital. Equally important is the development of efficient and diversified capital markets with sufficient instrument in order to make wise choices, while borrowers should have appropriate mechanisms to tap long-term domestic savings. At the same time, strong financial institutions should be able to manage external volatility to the level that it is not harmful to the organizations and the overall system. Strength of financial institutions can be instilled through promotion of good governance and ethics among financial executives. Strong financial institutions should distribute needed credit to local communities and small investors with relevant potential, not only to strong investors. Appropriate financial strategies and foreign exchange rate are also important factors in the process of immunizing the country against external volatility. A flexible foreign exchange rate and inflation targeting serve as a viable option in line with the perspective of the sufficiency economy.

From the experiences during the 1997 crisis, the Office of the National Economic and Social Development Board (NESDB) has adopted the sufficiency economy bestowed by His Majesty the King as a guiding philosophy in the $10^{\text {th }}$ National Economic and Social Development plan, which has the objectives of (1) people-centered development; (2) balancing between three capitals: economic, social, natural resources and environment, and (3) leading to the green and happiness society. Nevertheless, the application of the philosophy is not limited to the national level. The philosophy is applicable to people from all walks of life and at all level as shown in the table 5 .

Table 5

\begin{tabular}{|l|l|}
\hline \multicolumn{1}{|c|}{ Level of application } & \multicolumn{1}{c|}{ Application of the philosophy of sufficiency economy } \\
\hline Individual and house hold & - Reasonable behavior in investment and consumption(e.g. better individual and family \\
& financial planning, limiting unnecessary luxurious consumption) \\
& - Ethical behavior \\
& - Altruistic behavior \\
\hline Corporate Sector & - Risk consciousness/ awareness \\
& - Good corporate governance \\
& - Corporate social responsibility \\
& - Ethical/ responsible to stakeholders \\
\hline Economic Policy & - Conscience in economic management (fiscal discipline, etc.) \\
& - Business growth and stability \\
& - Sustainable growth/ suitable development \\
& - Fair distribution \\
& - Fair competition \\
& - Immunization against global risks \\
& - Strengthening impoverished rural communities \\
\hline
\end{tabular}

Despite different applications, they share the same goal of balanced and sustainable development. In conclusion, if Thai people as a whole can follow the middles path guided by the sufficiency economy, know what you are doing, be honest and persevere, take a middle path, avoid extremes, be sensible and insightful in making decisions, and build protection against shocks.

\section{CONCLUSION}

The fundamental approach to the sufficiency economy is the holistic adaptation of attitude, behavior, and way of life both the micro and macro levels. For concrete realization, application of the philosophy needs due consideration, prudence, determination and patience. It should be noted that the sufficiency economy concept is 
much broader than self-sufficiency. It emphasizes the middle path approach as mode of conduct by all groups to achieve moderation in life. Sufficiency means satisfying enough, minimizing greedy, being reasonable, and applying moderation. It enables people to better cope with external and internal shocks and live more sustainable. Without them, one cannot achieve sufficiency economy.

The sufficiency economy philosophy is not against but, on the other hand, in support of the market economy regime. The concept of good governance embodied and implied by the philosophy could verify that it, in fact, complements the market economy philosophy. If, for example, all participants in business activity focus on the application of good governance, a market economy can certainly function more effectively without fraud, corruption and distortion and, hence, result in better economic efficiency and performance.

The lessons learnt from the financial crisis in 1997 and the not-so-sufficient economic behaviors in the past remind and keep all Thai in perspective. With the sufficiency economy concept as a guidance of economic activities as well as ways of life, hopefully, Thailand will be able to develop with a balanced strategy so as to modernize in line with the force of globalization while shielding against inevitable shocks and excesses that arise occurring as a result of globalization. Ultimately, we will not have to go through such a crisis again.

\section{AUTHOR INFORMATION}

Dr. Vilasinee Bunyasrie Education: Ph.D. in Economics, Department of Economics, University of Hawaii at Manoa, 2005. M.A. in International Economics and Finance (English Program), Department of Economics, Chulalongkorn University, 1995. B.E., Department of Economics, Chulalongkorn University, 1993. Current position: Associate Dean for Student Affairs, Bangkok University International College November 2009 - present. Associate Dean, School of Economics, Bangkok University: June 2008 - October 2009. Assistant Dean, School of Economics, Bangkok University: November 2007 - May 2008. Chairperson of International Economic Department, School of Economics, Bangkok University: June 2006 - October 2007. Faculty, School of Economics, Bangkok University: June 2005 - May 2006.

\section{REFERENCES}

1. Auansakul, A. (2006). Sufficiency Economy and Market Economy. International Institute for Trade and Development.

2. Corsetti, G., Pesenti, P. and Roubini, N. (1998). What Caused the Asian Currency Crisis and Financial Crisis? Part I: A Macroeconomic Overview. NBER Working Paper, No. 6833 (December).

3. Corsetti, G., Pesenti, P. and Roubini, N. (1998). What Caused the Asian Currency Crisis and Financial Crisis? Part I: The Policy Debate. NBER Working Paper, No. 6834 (December).

4. Frederic, M. S. (1996). Understanding Financial Crises: A Developing Country Perspective. NBER Working Paper, No. 5600 (May).

5. Graciela, K., Lizondo, A. and Reinhart, A. M. (1997). The Twin Crises: The causes of Banking and Balance of Payments Problems. Mimeo, Federal Reserve Board.

6. Graciela, K., Lizondo, A. and Reinhart, A. M. (1998). Leading Indicators of Currency Crises. IMF Staff Papers. (March).

7. H.E. Genral Tinsulanonda, P. Sufficiency Economy: His Majesty's Philosophy of Development. The Leadership Forum 2001. Bangkok. 15 March 2001.

8. Krongkaew, M. (2003). The Philosophy of Sufficiency Economy. Kyoto Review. Issue 3 (October).

9. Menzie, C. (1998). Before the Fall: Were East Asian Currencies Over Valued?. NBER Working Paper, No. 6491 (March).

10. Morris, G. (1998). The Asia Financial Crisis: Causes, Cures, and Systematic Implications. Policy Analyses in International Economics, No.55, Washington, DC: Institute for International Economics.

11. Pedro, A., Bhattacharya, A., Claessens, S., Ghosh, A. and Hernandez, L. (1998). Volatility and Contagion in Financially-Integrated World: Lessons from East Asia's Recent Experience. Paper presented at the PAFTAD 24 Conference "Asia Pacific Financial Liberalization and Reform," Chiangmai, Thailand 20-22 May. 
12. Roberto, C. and Velasco, A. (1998b). Financial Crises in Emerging Markets: a Canonical Model. NBER Working Paper, No. 6606 (June).

13. Ronald, M. and Pill, H. (1996). Credible Liberalization and International Capital Flows: the Over borrowing Syndrome, in Ito, T. and Kruger, A.O. (editors). Financial Deregulation and Integration in East Asia, The University of Chicago Press.

14. Rudiger, D., Goldfajn, I. and Valdes, R. O. (1995). Currency Crises and Collapses. Brooking Papers on Economic Activity I. pp.219-270.

15. Steven, R. and Sachs, J. (1998). The Onset of the East Asian Financial Crisis. NBER Working Paper, No. 6680 (August).

16. http://www.chaipat.or.th/journal/dec00/eng/e-economy.html, Sufficiency Economy: Direction of the Ninth National Economic and Social Development Plan, in Pursuit of His Majesty's Philosophy.

17. Sufficiency Economy and Human Development. Thailand Human Development report 2007. UNDP. Bangkok.

18. Sawanraks, R. (1999). Sufficiency Economy. Summary of Discussion: The 1999 TDRI Year-end Conference. 
NOTES 